\title{
Celiac Disease and its Association with Infertility and Obstetric Complications in Women
}

\author{
Taufner $\mathrm{GH}^{1 *}$, Barcelos $\mathrm{IF}^{1}$, Lunz $\mathrm{TM}^{3}$ and Destefani $\mathrm{AC}^{4}$ \\ ${ }^{1}$ Department of Biotechnology, Federal University of Espírito Santo, Brazil \\ ${ }^{2}$ Department of Nutrition, Federal University of Espírito Santo, Brazil \\ ${ }^{3}$ Department of Biochemistry, Federal University of Espírito Santo, Brazil
}

Submission: January 24, 2017; Published: February 20, 2017

*Corresponding author: Taufner GH, Department of Biotechnology, Federal University of Espírito Santo (UFES), Av Marechal Campos 1468, Maruípe, Vitória/ES, CEP 29043-900, Brazil, Email: Gabrielhtaufner@hotmail.com

\begin{abstract}
Celiac disease is a multisystem resistant based issue that is activated by the ingestion of gluten in hereditarily defenseless people. The predominance of celiac disease has ascended in late decades and is at present around $1 \%$ in most Western populaces. The explanation behind this ascent is obscure, albeit natural elements identified with the cleanliness speculation are suspected. The pathophysiology of celiac disease includes both the natural and versatile insusceptible reaction to dietary gluten. Clinical components are various and incorporate gastrointestinal side effects, metabolic bone disease, barrenness, and numerous different appearances. In spite of the fact that a sans gluten eating regimen is powerful in many patients, this eating routine can be troublesome and can restrain personal satisfaction; thus, non-dietary treatments are at different phases of improvement. This survey likewise covers non-celiac gluten affectability. The pathophysiology of this clinical phenotype is inadequately seen, however it is a reason for expanding enthusiasm for sans gluten consumes less calories in the overall public. Throughout the most recent decade when the commonness of the disease increments quickly affirming the relationship between coeliac disease and a scope of regenerative issue. Issues here are for the most part affirmed in untreated ladies. Among the atypical side effects of coeliac disease additionally incorporate fruitlessness, for example, deferred onset of monthly cycle, early menopause, optional amenorrhea, barrenness and pregnancy entanglements, for example, repetitive premature births, intrauterine fetal development confinement, little hatchling for gestational age, low birth weight and untimely birth. Celiac disease maybe significant increases in spontaneous abortion, premature delivery, and later age of menarche.
\end{abstract}

Keywords: Celiac disease; Pregnancy; Obstetric complications; Fetal growth restriction

\section{Introduction}

Celiac disease (DC) is an autoimmune disease that affects genetically predisposed individuals through the ingestion of foods containing gluten proteins, the main compound of wheat, oats, rye, barley and malt [1]. The disease is characterized by changes in the small intestine of the carriers as the diminution of the intestinal villi and, consequently, of the area of nutrient absorption [2].

The prevalence of the disease among countries and in European or European ancestry populations varies from 0.3 to $1.0 \%$, and it is believed that much still remains undiagnosed $[1,3,4]$. In Brazil, official statistical data are unknown, however, it is estimated that 300,000 Brazilians are carriers of the disease [1]. In Europe and the United States, prevalence ranges from 1: 100 to 1: 200 individuals respectively [5]. Numbers close to a study carried out in São Paulo (Brazil), in which it demonstrated the prevalence of one celiac for each 214 inhabitants [6].

CD can present in a classic, non-classical or asymptomatic way, with no or several signs and symptoms, which can often be correlated with associated complications [7-10]. Despite the recent advances in the clarification of the association of $C D$ with several pathologies, its role in complications related to the reproductive life of women is still little elucidated [11-15]. This article aims to review the association between $C D$, infertility and the main complications that occur during pregnancy.

\section{Fundamental Concept}

Celiac disease is a permanent intolerance to gluten, characterized by total or subtotal atrophy of the proximal small intestinal mucosa, resulting in malabsorption of food 
in genetically susceptible individuals [7-16]. It starts as an inflammation in the duodenum (duodenitis, infiltration of cells of the immune system like the T lymphocytes). As gluten intake is maintained, other mucosal changes occur, such as stretching of the crypts and atrophy of the villi that line the duodenum, where the absorptive process of many nutrients occurs. The celiac patient has an abnormal immune response of the individual to peptides derived from gliadin and glutenin. Sensitive CD4+T lymphocytes recognize multiple gluten epitopes through presentation through the DQ2 and DQ8 molecules. Activated lymphocyte clones proliferate and produce various proinflammatory cytokines responsible for the stimulation of cytotoxic $\mathrm{T}$ cells by promoting cell infiltrate and producing metalloproteinases that damage the extracellular matrix [10].

Initially, MacDonald and colleagues, based on family studies and using small intestinal biopsies, suggested that there was an autosomal dominant inheritance for DC [17]. However, the pathophysiology of CD is much more complex because it results from the interaction between environmental, genetic and immunological factors [16].

CD is a multifactorial disease, therefore, of difficult genetic characterization [18]. The way out to uncover the basis of the disease and develop strategies for detection, diagnosis and prevention is the identification of susceptibility genes [19]. The celiac patient has a genetic defect that directly affects the major histocompatibility complex (MHC), also known as the human leukocyte antigen (HLA) system, located on the short arm of chromosome six. This system is subdivided into three regions, called class I, II and III [20]. The class I region is composed mainly of the HLA-A, B, C loci and are coding for molecules present in almost all nucleated cells; the class II region is of great importance for the understanding of the genetic bases of DC, encompassing the HLA-DR, PD and DQ loci, being HLA-DR and DQ the most important when talking about gluten intolerance. This region encodes surface molecules in macrophages, dendritic cells, monocytes, B- and T-lymphocytes. The third and last region, class III, encodes components of the complement system that is extremely important in combating pathogens, and a range of enzymes Fernandes et al. [21]; Donadi [22]; Mackay et al. [23]. It was thought that two distinct unrelated loci were involved in the etiology of $\mathrm{CD}$, being a dominant inherited, this one linked to HLA-DR3, and the other in a recessive, non-HLA-linked form [24]. The correlation of these two loci is the fruit of discussion to this day. The association between DC and the HLA system is well established $[25,26]$.

Among several complex autoimmune diseases, CD has a strong association with HLA, and approximately $90-95 \%$ of celiac patients are associated with HLA-DQ2 (alleles DQA1*0501 and DQB1*0201) and the remainder with HLA-DQ8 (alleles DQA $1 * 0301$ and DQB1*0302). Although important, in some cases, HLA-DQ2 and DQ8 molecules are not sufficient to carry the phenotypic expression of CD. Therefore, because the disease is of a polygenic nature, it is believed that there are mutations not associated with HLA in patients with CD [27,28].

\section{Symptoms and Diagnosis}

There are three forms of clinical presentation of CD, classic, non classical or asymptomatic $[9,10,16]$. The classic form is characterized by the presence of chronic diarrhea, usually accompanied by abdominal distension, weight loss, lack of appetite, vomiting and iron deficiency anemia. In addition, patients may present with decreased subcutaneous tissue, gluteal muscle atrophy, and mood swings [29]. The nonclassical form is characterized by a mono or oligosymptomatic framework, where the digestive manifestations are absent or; when present, occupy a second plane. Celiac patients may present with isolated manifestations, such as short stature, iron deficiency anemia refractory to oral iron replacement, folate and vitamin B12 deficiency anemia, osteoporosis, dental enamel hypoplasia, arthralgia or arthritis, constipation refractory to treatment, pubertal delay, irregular menstrual cycle, sterility, recurrent abortions, ataxia, epilepsy (isolated or associated with cerebral calcification), peripheral neuropathy, myopathy, psychiatric manifestations (depression, autism, schizophrenia), recurrent aphthous ulcer. Elevation of liver enzymes without apparent cause, adynamia, weight loss without apparent cause, edema of abrupt onset after infection or surgery and non-ulcer dyspepsia $[29,30]$. If not treated correctly, the classic and nonclassical form may have severe evolution, known as celiac crisis. This potentially fatal complication is characterized by the presence of diarrhea with severe hypotonic dehydration, abdominal distension due to hypopotassemia and severe malnutrition, in addition to other manifestations such as hemorrhage and tetany [31]. The asymptomatic form is characterized by serological and histological alterations of the DC-compatible small intestinal mucosa. This situation can be verified especially among risk groups for $\mathrm{CD}$, such as first-degree relatives of celiac patients, and has been recognized more frequently in the last two decades, after the development of the serological markers for the disease [16,32-34].

Most DC cases have a difficult diagnosis to make. Around 10\% of the cases there is difficulty of diagnosis by discordant findings between serology, clinical and histology [35]. The diagnosis of this disease is based on serological tests that detect anti-endomysial antibodies (EMA), antigliadin (AGA) and anti-transglutaminase (AtTG) [36]. A positive serological test suggests the diagnosis for $\mathrm{CD}$, but the same can only be confirmed through the distal duodenal biopsy, a gold standard test, which shows a change in the histopathological characteristics [37-39]. About duodenal biopsy, there is a need to perform a minimum of three to confirm the diagnosis of the disease: the first one reveals atrophy of the intestinal villi, the second one after treatment to demonstrate the recovery of villi and crypts, and the third And last one that shows the damages caused by the gluten intake $[15,40]$. 


\section{Treatment}

The only treatment available for celiac disease is the exclusion of gluten from the diet $[16,41,42]$ No food or medication containing wheat, rye, or barley gluten or its derivatives in quantities over 20 parts per million (ppm) may be ingested by a celiac patient [43]. After excluding it from the diet, approximately $70 \%$ of the patients reported improvement of symptoms within two weeks after the start of the gluten-free diet [44]. Many complications of the disease are preventable with a gluten-free diet $[45,46]$. With strict dietary adherence, the titer of antibodies specific for celiac disease normalizes. Although the villous changes begin to improve within months after the onset of a gluten-free diet, complete histologic resolution may take years and may not be achieved in each patient $[47,48]$. There is evidence that the lack of histological resolution may depend on the persistent consumption of gluten [49]. The safe limit of gluten intake varies from patient to patient and was considered to be $10-100 \mathrm{mg} /$ day, although a subsequent study indicated that the upper limit should not exceed $50 \mathrm{mg} /$ day [50].

\section{General Complications}

If a suitable diet is not introduced, celiac patients may present with several types of malignant and non-malignant complications that encompass several other organs and systems, and which often do not demonstrate important postoperative symptoms. As non-malignant complications, we highlight osteoporosis, infertility, obstetric complications, pulmonary hemosiderosis, neurological and psychiatric disorders, intestinal bleeding and intestinal ulcers, as well as an infinity that has not yet been studied [15,51-54]. On the other hand, malignant complications, of a more severe nature, can be highlighted in lymphoma in the small intestine (more frequent), carcinoma of the esophagus and pharynx, as well as adenocarcinoma of the small intestine that still has little etiopathogenesis [55-57]. In addition, CD is being correlated with several autoimmune diseases, including type I diabetes, Down syndrome and Turner syndrome [58,59].

\section{Obstetric complications}

Infertility: There is controversy regarding the possible association between $\mathrm{CD}$ and female reproductive tract dysfunction. Several studies have suggested that before the installation of a gluten-free diet, women with CD would have a higher prevalence of infertility, recurrent abortions, restricted intrauterine growth, and stillbirth $[13,60,61]$.

The hypothesis of the association between celiac disease and infertility was first reported in 1970, where Morris and colleagues describe three patients with untreated celiac disease and infertility who became pregnant after the onset of the gluten-free diet [62].

The high prevalence of celiac disease in infertile women has been documented by several authors, and it is estimated that the disease affects approximately 4 and $8 \%$ of women diagnosed with infertility without apparent cause [63-66]. One of the first studies of the association with infertility consisted of a study carried out with 74 women, carried out in 1982.It was observed that patients with normal diet presented short reproductive period, infertility, besides a higher incidence of spontaneous abortions, unlike patients with diet gluten-free diet that presented normal birth rates in addition to healthy childrenp [61].

A recent study using 170 Brazilian women and aimed at the identification of celiac disease, identified in a subgroup of 29 infertile women the celiac seropositivity in three $(10.3 \%)$ of the patients with unexplained infertility Machado et al. [11]. In another similar study carried out in Brazil, with a group of 200 women with reports of difficulty in becoming pregnant, three patients (1.5\%) with positive serology for anti-transglutaminase antibody (tTG) were identified, with a diagnosis of CD confirmed by endoscopic duodenal biopsy and histopathological examination. In the control group with 400 women, there were no positive cases [51].

Despite numerous reports of association between infertility and DC, one cannot confirm with absolute certainty that DC is actually responsible for infertility. Tata and colleagues found similar fertility rates among women with celiac disease and controls. However, age-specific fertility rates varied, showing that celiac women were more likely to have older children [67]. In a study of fertility in celiac women conducted in Sweden, 11,000 women of reproductive age and positive biopsy for celiac disease were used. In this study, Zugna et al. [68] showed that celiac disease was not associated with decreased fertility. However, fertility was reduced in the two years prior to the diagnosis (fertility risk ratio was 0.63 [95\% CI: 0.57-0.70]), and this returned to normal intervals after Diagnosis and treatment [68].

In contrast to most of the few publications to date on infertility correlated with $\mathrm{CD}$ and as reported above, a study conducted in the UK using 2,426,255 women as potential present in the database of the UK health care system, observed that the rate of infertility in clinically recorded celiac patients correlated with the rate found in healthy people. However, infertility in celiac patients was $41 \%$ higher than in healthy subjects when it ranked them by age 25-29 years [69]. Despite the impressive number of individuals studied, the study presents the bias of studies whose data were collected in medical records, which do not always express the truth. Given the great importance of the association of infertility even without being recurrent, it is essential to diagnose celiac disease in the population with poor reproductive outcome because a simple therapeutic intervention, such as a gluten-free diet, can result in conception and a favorable outcome of pregnancy.

Pregnancy complications: Malabsorption of nutrients caused by intestinal villi impairment in CD can directly interfere with embryogenesis, altering the nutritional status of the mother 
and the embryo to be developed. This lack of control of maternal and fetal nutritional intake can lead to several disorders related to embryo development, such as intrauterine growth restriction (IUGR), recurrent spontaneous abortion (RSA), stillbirth and congenital malformations [60,70-75].

Intrauterine growth restriction is a fetal pathology defined by a birth weight of less than $10 \%$ based on a standard curve of the general population [76]. The IUGR is a major complication of pregnancy and is responsible for a 5-20 fold increase in perinatal mortality and for considerable perinatal morbidity. It can also have lifelong consequences ranging from delayed neurodevelopment to an increased risk of developing hypertension, heart disease, and diabetes [77,78]. This condition could be a consequence of extrinsic factors or intrinsic growth retardation. When all causes are excluded it can be defined as celiac intrauterine growth retardation.

The recurrent spontaneous abortion (RSA) is defined as the presence of two or more miscarriages of unknown origin. It is believed that in celiac patients there is an association with some abnormalities in the vascular endometrium and an altered mechanism of trophoblastic endometrial invasion and implantation [79].

An American study analyzed the prevalence of undiagnosed celiac disease in patients with RSA, fetal death, IUGR and infertility. Were analyzed 104 women with idiopathic RSA history, 104 women with a history of idiopathic fetal death, 150 women with idiopathic IUGR, 230 women with unexplained infertility and 305 women with a normal obstetric history. Founded 7 (6.7\%) of 104 individuals in the group with a history of recurrent abortions, 6 (5.7\%) of 104 women in the fetal death group, $13(5.6 \%)$ of 230 women in the infertility group, $14(9.3 \%)$ of 150 women in the idiopathic intrauterine growth restriction group, and 4 (1.3\%) of 305 in the control group tested positive for anti-tissue transglutaminase (tTG) IgA antibody. The seroprevalence of the anti-endomysial IgA and tissue antitransglutaminase (tTG) IgA antibody was similar in all groups, i.e., spontaneous recurrent abortion, stillbirths, infertility and unexplained idiopathic intrauterine growth $(\mathrm{P}>0.05)$ [52].

In another study in India, Sharma et al. evaluated two groups of 45 Indian women, with and without IUGR, to analyze their indecency in celiac patients, associating positive cases with the presence of anti-transglutaminase antibodies (tTG). Two (4.4\%) cases from the group of women with IGR tested positive for tTG antibodies, while none of the controls were positive [80].

In a study that aimed to evaluate the frequency of celiac disease through the identification of anti-endomysial and antitransglutaminase antibodies (tTG) in women with recurrent abortion and idiopathic intrauterine growth retardation, three groups were used: 44 patients with RSA, 39 with IUGR and 50 healthy. Patients in the first and second groups had a significantly higher frequency of serologic markers than controls. Three (8\%) patients with IUGR and six (15\%) patients with IUGR had positive anti-endomysial and anti-transglutaminase (tTG) serologic tests and none of the controls had antibody positivity; of the 9 positive patients, 8 had confirmation of jejunal biopsy tests. In another study by Moleski et al. [14] women with celiac disease had higher rates of spontaneous abortions than healthy women (50.6\% vs $40.6 \%$ ) [14]. Women with undiagnosed celiac disease were shown to have up to a relative ninefold increased risk of recurrent miscarriage compared to treated patients $[60,71]$.

Other studies have demonstrated an association that is not as strong or statistically significant [67-81] Studies observed that the abortion rate in women with celiac disease was almost double that of controls, but this association was statistically insignificant [81] and abortions were slightly more common in women with celiac disease (RR 1.31 [95\% CI, 1.06-1.61]) [67].

Adopting an exempt diet can reduce the relative risk of miscarriage by about nine times [71]; this statement was proved by a positive pregnancy outcome when a gluten-free diet was adopted [82].

Pathophysiology of obstetric complications: The mechanism underlying these disorders has not yet been fully elucidated and some authors advocate malnutrition and consequent deficiencies of zinc, iron and folate as a likely cause. However, it is important to remember that infertility may occur in the absence of overt malnutrition and may be the only symptom present in patients with undiagnosed subclinical CD [64]. Some authors call attention to the evident correlation between the time of exposure to gluten and the progressive increase of autoimmune disorders [83]. The presence of autoimmunity in individuals with CD can vary between extremes of $5.1 \%$ among children under two years and $34 \%$ in adults over 20 years of age [84]. These authors raise the possibility that the presence of specific antibodies and T-cell mediated autoimmune response could be associated with the outbreak of dysfunction of the female reproductive tract.

Celiac disease can lead to adverse pregnancy outcomes through a number of mechanisms. The negative influence on nutritional status due to malabsorption of mucosal inflammation has been postulated as the probable pathogenesis for both reproductive and pregnancy complications. Malnutrition has not been a consistent feature among women with celiac disease and obstetric complications $[71,81,85]$. Gliadin may also induce an inflammatory reaction with the production of associated cytokines that may adversely affect the fetus $[72,86]$.

Recent research has shown that self maternal antibodies bind to placental tissue transglutaminase and interfere with the transfer of nutrients, alter the dynamics leading to cell apoptosis, and damage secretory function placenta [87]. Studies further demonstrated impaired invasiveness, ability to migrate and interact with reduced extracellular matrix, and altered apoptosis when trophoblastic tissue was exposed to anti-tTG IgG [88]. 
These data suggest a possible pathogenesis for early pregnancy loss and RSA in untreated maternal celiac disease. Adherence to a gluten-free diet has been shown to reduce circulating antibodies and the risk of fetal growth restriction during pregnancy [72].

\section{Conclusion}

Despite the innumerable reports with different positions on the association between celiac disease, infertility and obstetric complications, it is still not possible to say with certainty if there is the influence of $\mathrm{CD}$ in these complications that affect the reproductive life of women, since the number of existing cases does not currently a significant statistical value. However, one should not exclude any hypothesis since there have been reports that with the implementation of the treatment the obstetric and infertility related problems presented considerable improvements.

\section{References}

1. Araújo HMC, Araújo WMC, Botelho RBA, Zandonadi RP (2010) Doença celíaca, hábitos e práticas alimentares e qualidade de vida. Rev Nutr 23(3): 467-474.

2. Casellas F, Rodrigo L, Vivancos JL, Riestra S, Pantiga C, et al. (2008) Factors that impact health-related quality of life in adults with celiac disease: a multicenter study. World J Gastroenterol 14(1): 46-52.

3. Hill ID, Dirks MH, Liptak GS, Colletti RB, Fasano A, et al. (2005) Guideline for the diagnosis and treatment of celiac disease in children: recommendations of the North American Society for Pediatric Gastroenterology, Hepatology and Nutrition. J Pediatr Gastroenterol Nutr 40(1): 1-19.

4. Mustalahti K, Catassi C, Reunanen A, Fabiani E, Heier M, et al. (2010) The prevalence of celiac disease in Europe: results of a centralized international mass screening project. Ann Med 42(8): 587-595.

5. Fasano A, Catassi C (2005) Coeliac disease in children. Best Pract. Res Clin Gastroenterol 19: 467-478.

6. Oliveira RP, Sdepanian VL, Barreto JA, Cortez AJ, Carvalho FO, et al. (2007) High prevalence of celiac disease in Brazilian blood donor volunteers based on screening by IgA anti tissue transglutaminase antibody. Eur J Gastroenterol Hepatol 19(1): 43-49.

7. Sdepanian VL, Morais MB De, Fagundes-Neto U (1999) Doença celíaca: a evolução dos conhecimentos desde sua centenária descrição original até os dias atuais. Arq Gastroenterol 36(4): 244-257.

8. Sdepanian VL, Morais MB de, Fagundes-Neto U (2001) Doença celíaca: características clínicas e métodos utilizados no diagnóstico de pacientes cadastrados na Associação dos Celíacos do Brasil. J Pediatria 77(2): 131-138

9. Shannahan S, Leffler DA (2017) Diagnosis and Updates in Celiac Disease. Gastrointest. Endosc Clin N Am 27(1): 79-92.

10. Nobre SR, Silva T, Cabral JEP (2007) Doença celíaca revisitada. J Port Gastrenterologia 14(4): 184-193.

11. Machado AP, Silva LR, Zausner B, Oliveira Jde A, Diniz DR, et al. (2013) Undiagnosed celiac disease in women with infertility. J Reprod Med 58(1): 61-66.

12. Saccone G, Berghella V, Sarno L, Maruotti GM, Cetin I, et al. (2016) Celiac disease and obstetric complications: a systematic review and metaanalysis. Am J Obstet Gynecol 214(2): 225-234.
13. Casella G, Orfanotti G, Giacomantonio L, Bella CD, Crisafulli V, et al. (2016) Celiac disease and obstetrical-gynecological contribution. Gastroenterol Hepatol bed to bench 9(4): 241-249.

14. Moleski SM, Lindenmeyer CC, Veloski JJ, Miller RS, Miller CL, et al (2015) Increased rates of pregnancy complications in women with celiac disease. Ann Gastroenterol 28(2): 236-240.

15. Fiolková K, Biringer K, Hrtánková M, Fiolka R, Danko J (2016) Coeliac disease as a possible cause of some gynecological and obstetric abnormalities. Ces Gynekol 81(6): 470-476.

16. Moscoso JF, Quera PR (2016) Enfermedad celíaca. Revisión Rev Med Chil 144: 211-221.

17. MacDonald WC, Dobbins WO, Rubin CE (1965) Studies of the Familial Nature of Celiac Sprue Using Biopsy of the Small Intestine. N Engl J Med 272: 448-456.

18. Jenuth JP, Peterson AC, Fu K, Shoubridge EA (1996) Random genetic drift in the female germline explains the rapid segregation of mammalian mitochondrial DNA. Nat Genet 14(2): 146-151.

19. Clot F, Babron MC (2000) Genetics of celiac disease. Mol Genet Metab 71: 76-80.

20. Turner D (2004) The human leucocyte antigen (HLA) system. Vox Sang 87(Suppl1): 87-90.

21. Fernandes APM, Maciel LMZ, Foss MC, Donadi EA (2003) Como entender a associação entre o sistema HLA e as doenças auto-imunes endócrinas. Arq Bras Endocrinol Metabol 47(5): 601-611.

22. Donadi EA (2000) Como Entender A Nomenclatura E Os Mecanismos De Associação Entre Os Antígenos E Os Alelos De Histocompatibildade Com As Doenças. Med (Ribeirao Preto Online 33: 7-18.

23. Mackay IR, Rosen FS, Klein J, Sato A (2000) The HLA System. N Engl J Med 343: 702-709.

24. Peña AS (1978) Genetic basis of gluten-sentitive enteropathy. Gastroenterology 75(2): 230-235.

25. Houlston RS, Ford D (1996) Genetics of coeliac disease. QJM 89(10): 737-744.

26. Sollid LM (2000) Molecular Basis of Celiac Disease. Annu Rev Immunol 18: 53-81.

27. Romanos J, van Diemen CC, Nolte IM, Trynka G, Zhernakova A, et al (2009) Analysis of HLA and non-HLA alleles can identify individuals at high risk for celiac disease. Gastroenterology 137(3): 834-840.

28. Pietzak MM, Schofield TC, McGinniss MJ, Nakamura RM (2009) Stratifying risk for celiac disease in a large at-risk United States population by using HLA alleles. Clin Gastroenterol Hepatol 7(9): 966971.

29. Ludvigsson (2013) The Oslo definitions for coeliac disease and related terms. Gut 62(1): 43-52.

30. Santonicola A, Iovino P, Cappello C, Capone P, Andreozzi P, et al. (2011) From menarche to menopause: the fertile life span of celiac women. Menopause 18(10): 1125-1130.

31. Sbai W (2016) Celiac crisis in a multi-trauma adult patient. Clin Res Hepatol Gastroenterol 40(3): e31-e32.

32. Nachman F, Maurino E, Vazquez H, Sfoggia C, Gonzalez A, et al. (2009) Quality of life in celiac disease patients. Dig Liver Dis 41(1): 15-25.

33. Green PHR, Rostami K, Marsh MN (2005) Diagnosis of coeliac disease. Best Pract Res Clin Gastroenterol 19: 389-400.

34. Many N, Biedermann L (2016) Zöliakie beim Erwachsenen. Praxis Ber 1994 105: 803-810. 
35. Silva TS, da Ge, Furlanetto TW (2010) Diagnóstico de doença celíaca em adultos. Rev Assoc Med Bras 56(1): 122-126.

36. Leffler DA, Schuppan D (2010) Update on serologic testing in celiac disease. Am J Gastroenterol 105(12): 2520-2524.

37. Oberhuber G, Granditsch G, Vogelsang H (1999) The histopathology of coeliac disease: time for a standardized report scheme for pathologists. Eur J Gastroenterol Hepatol 11(10): 1185-1194.

38. Marsh NM, Johnson WM, Rostami K (2015) Mucosal histopathology in celiac disease: a rebuttal of Oberhuber's sub-division of Marsh III. Gastroenterol. Hepatol from bed to bench 8(2): 99-109.

39. Ludvigsson JF, Bai JC, Biagi F, Card TR, Ciacci C, et al. (2014) Diagnosis and management of adult coeliac disease: guidelines from the British Society of Gastroenterology. Gut 63(8): 1210-1228.

40. Nascimento, kamila de O, Jacinho MIM, Takeiti CY (2012) Doença Celíaca: Sintomas, Diagnóstico e Tratamento Nutricional. Saúde em Rev 11: 53-63.

41. Green PHR, Cellier C (2012) Celiac disease. N Engl J Med 367: 24192426.

42. Ciacci C, Ciclitira P, Hadjivassiliou M, Kaukinen K, Ludvigsson JF, et al. (2015) The gluten-free diet and its current application in coeliac disease and dermatitis herpetiformis. United European Gastroenterol J 3(2): 121-135.

43. Codex Alimentarius Comission (2014) Norma relativa a los alimentos para regímenes especiales destinados a personas intolerantes al gluten.

44. Corazza GR, Di Stefano M, Mauriño E, Bai JC (2005) Bones in coeliac disease: diagnosis and treatment. Best Pract. Res Clin Gastroenterol 19(3): 453-465.

45. Collin P (2005) Should adults be screened for celiac disease? What are the benefits and harms of screening? Gastroenterology 128(4 Suppl 1): S104-S108.

46. Hoffenberg EJ (2005) Should all children be screened for celiac disease? Gastroenterology 128 (Suppl 1): S98-S103.

47. Moreno ML, Cebolla Á, Muñoz-Suano A, Carrillo-Carrion C, Comino I, et al. (2017) Detection of gluten immunogenic peptides in the urine of patients with coeliac disease reveals transgressions in the gluten-free diet and incomplete mucosal healing. Gut 66(2): 250-257.

48. Sugai E, Nachman F, Váquez H, González A, Andrenacci P, et al. (2010) Dynamics of celiac disease-specific serology after initiation of a glutenfree diet and use in the assessment of compliance with treatment. Dig Liver Dis 42(5): 352-358.

49. Kelly CP, Bai JC, Liu E, Leffler DA (2015) Advances in diagnosis and management of celiac disease. Gastroenterology 148(6): 1175-1186.

50. Forbes GM (2015) If only my celiac patients and I knew that. Clin Gastroenterol Hepatol 13(3): 614-615.

51. Martins CL, Lenora G, Luiz Tauil P, Rocha Picanco M, Maria OG de, et al. (2006) Doença celíaca e infertilidade feminina: associação freqüentemente negligenciada. Rev Bras Ginecol e Obs 28(10): 601606.

52. Kumar A, Meena M, Begum N, Kumar N, Gupta RK, et al. (2011) Latent celiac disease in reproductive performance of women. Fertil Steril 95(3): 922-927.

53. Fitzpatrick LA (2002) Secondary Causes of Osteoporosis. Mayo Clin Proc 77(5): 453-468.

54. Nacaroglu HT, Sandal OS, Bag O, Erdem SB, Bekem Soylu O, et al. (2015) Association of Celiac Disease With Idiopathic Pulmonary Hemosiderosis; Lane Hamilton Syndrome. Iran J Pediatr 25(5): e3312.
55. Freeman HJ (2009) Adult celiac disease and its malignant complications. Gut Liver 3(4): 237-246.

56. Brousse N, Meijer JWR (2005) Malignant complications of coeliac disease. Best Pract Res Clin Gastroenterol 19(3): 401-412.

57. Catassi C, Bearzi I, Holmes GKT (2005) Association of celiac disease and intestinal lymphomas and other cancers. Gastroenterology 128(4 Suppl 1): S79-S86

58. Francisco M de Melo, Maria SM Cavalcanti, Severino B dos Santos, Ana KBF, Lopes Felipe AA, et al. (2005) Associação Entre Marcadores Sorológicos de Doença Celíaca e das Doenças Autoimunes da Tireóide Francisco. Arq Bras Endocrinol Metab 49(4): 542-547.

59. Kumar V, Rajadhyaksha M, Wortsman J (2001) Celiac diseaseassociated autoimmune

60. endocrinopathies. Clin Diagn Lab Immunol 8(4): 678-685.

61. Gasbarrini A, Torre ES, Trivellini C, De Carolis S, Caruso A, et al. (2000) Recurrent spontaneous abortion and intrauterine fetal growth retardation as symptoms of coeliac disease. Lancet 356(9227): 399400.

62. Ferguson R, Holmes GK, Cooke WT (1982) Coeliac disease, fertility, and pregnancy. Scand J Gastroenterol 17(1): 65-68.

63. Morris J, Adjukiewicz AB, Read AE (1970) Cœliac Infertility: An Indication For Dietary Gluten Restriction? Lancet 295(7640): 213-214.

64. Martinelli P, Troncone R, Paparo F, Torre P, Trapanese E, et al. (2000) Coeliac disease and unfavourable outcome of pregnancy. Gut 46(3): 332-335.

65. Collin P, Vilska S, Heinonen PK, Hällström O, Pikkarainen P (1996) Infertility and coeliac disease. Gut 39(3): 382-384.

66. Meloni GF, Dessole S, Vargiu N, Tomasi PA, Musumeci S (1999) The prevalence of coeliac disease in infertility. Hum Reprod 14(11): 27592761.

67. Fortunato F, Martinelli D, Prato R, Pedalino B (2014) Results from Ad Hoc and Routinely Collected Data among Celiac Women with Infertility or Pregnancy Related Disorders: Italy, 2001-2011. Scientific World Journal 2014: 614269.

68. Tata LJ, Card TR, Logan RF, Hubbard RB, Smith CJ, et al. (2005) Fertility and pregnancy-related events in women with celiac disease: a population-based cohort study. Gastroenterology 128(4): 849-855.

69. Zugna D, Richiardi L, Akre O, Stephansson O, Ludvigsson JF (2010) A nationwide population-based study to determine whether coeliac disease is associated with infertility. Gut 59(11): 1471-1475.

70. Dhalwani NN, West J, Sultan AA, Ban L, Tata LJ (2014) Women With Celiac Disease Present With Fertility Problems No More Often Than Women in the General Population. Gastroenterology 147(4): 12671274 .

71. Salvatore S, Finazzi S, Radaelli G, Lotzniker M, Zuccotti GV, et al. (2007) Prevalence of undiagnosed celiac disease in the parents of preterm and/or small for gestational age infants. Am J Gastroenterol 102(1): 168-173.

72. Ciacci C, Cirillo M, Auriemma G, Di Dato G, Sabbatini F, et al. (1996) Celiac disease and pregnancy outcome. Am J Gastroenterol 91(4): 718722.

73. Ludvigsson JF, Montgomery SM, Ekbom A (2005) Celiac disease and risk of adverse fetal outcome: a population-based cohort study. Gastroenterology 129(2): 454-463.

74. Nørgård B, Fonager K, Sørensen HT, Olsen J (1999) Birth outcomes of women with celiac disease: a nationwide historical cohort study. Am J Gastroenterol 94(9): 2435-2440. 
75. Khashan AS, Henriksen TB, Mortensen PB, McNamee R, McCarthy FP, et al. (2010) The impact of maternal celiac disease on birthweight and preterm birth: a Danish population-based cohort study. Hum Reprod 25(2): 528-534.

76. McCarthy FP, Khashan AS, Quigley E, Shanahan F, O Regan P, et al. (2009) Undiagnosed maternal celiac disease in pregnancy and an increased risk of fetal growth restriction. J Clin Gastroenterol 43(8): 792-793.

77. Botero D, Lifshitz F (1999) Intrauterine growth retardation and longterm effects on growth. Curr Opin Pediatr 11(4): 340-347.

78. Kronenberg ME, Raz S, Sander CJ (2006) Neurodevelopmental outcome in children born to mothers with hypertension in pregnancy: the significance of suboptimal intrauterine growth. Dev Med Child Neurol 48(3): 200-206.

79. Osmond C, Barker DJ (2000) Fetal, infant, and childhood growth are predictors of coronary heart disease, diabetes, and hypertension in adult men and women. Environ Health Perspect 108(Suppl 3): 545553.

80. Daya S (1996) Evaluation and management of recurrent spontaneous abortion. Curr Opin Obstet Gynecol 8(3): 188-192.

81. Sharma KA, Kumar A, Kumar N, Aggarwal S, Prasad S (2007) Celiac disease in intrauterine growth restriction. Int J Gynecol Obstet 98(1): 57-59.

82. Martinelli D, Fortunato F, Tafuri S, Germinario CA, Prato R (2010) Reproductive life disorders in Italian celiac women. A case-control study. BMC Gastroenterol 10: 89.
83. Tursi A, Giorgetti G, Brandimarte G, Elisei W (2008) Effect of gluten-free diet on pregnancy outcome in celiac disease patients with recurrent miscarriages. Dig Dis Sci 53(11): 2925-2928.

84. Bustos D, Moret A, Tambutti M, Gogorza S, Testa R, et al. (2006) Autoantibodies in Argentine women with recurrent pregnancy loss. Am J Reprod Immunol 55(3): 201-207.

85. Ventura A (2002) Coeliac disease and the risk of autoimmune disorders. Gut 51(6): 897-898.

86. Sher KS, Mayberry JF (1996) Female fertility, obstetric and gynaecological history in coeliac disease: a case control study. Acta Paediatr Suppl 412: 76-77.

87. Wei SQ Fraser W, Luo ZC (2010) Inflammatory Cytokines and Spontaneous Preterm Birth in Asymptomatic Women. Obstet Gynecol 116(2 Pt 1): 393-401.

88. Anjum N, Baker PN, Robinson NJ, Aplin JD (2009) Maternal celiac disease autoantibodies bind directly to syncytiotrophoblast and inhibit placental tissue transglutaminase activity. Reprod Biol Endocrinol 7: 16.

89. Di Simone N, Silano M, Castellani R, Di Nicuolo F, D’Alessio MC, et al. (2010) Anti-tissue transglutaminase antibodies from celiac patients are responsible for trophoblast damage via apoptosis in vitro. Am J Gastroenterol 105(10): 2254-2261.

Your next submission with Juniper Publishers will reach you the below assets

- Quality Editorial service

- Swift Peer Review

- Reprints availability

- E-prints Service

- Manuscript Podcast for convenient understanding

- Global attainment for your research

- Manuscript accessibility in different formats

( Pdf, E-pub, Full Text, Audio)

- Unceasing customer service

Track the below URL for one-step submission https://juniperpublishers.com/online-submission.php 